\title{
Aquepts in South Mahanadi Delta of Odisha: Characteristics and Land Use Interpretation
}

\section{K. N. Mishra*, D. Jena and T. K. Samanta}

Dept. of Soil Science and Agricultural Chemistry, Orissa University of Agriculture and Technology, Bhubaneswar (751 003), India

\section{Article History}

Manuscript No. AR1690

Received in $16^{\text {th }}$ September, 2016

Received in revised form $4^{\text {th }}$ October, 2016

Accepted in final form $6^{\text {th }}$ October, 2016

\section{Correspondence to}

*E-mail: khiturajprav@yahoo.co.uk

\section{Keywords}

Aquepts, deltaic soils, gleying, episaturation, endosaturation

\begin{abstract}
The floodplain soils of South Mahanadi delta are dominantly Aquepts with characteristics associated with wetness. Four representative pedons of these Aquepts in a transect under South Mahanadi delta of Odisha were characterized and classified for land use interpretation. The soils are deep and the matrix colour are dominantly gray with hue of $2.5 \mathrm{Y}, 2.5 \mathrm{YR}, 10 \mathrm{YR}$, value of 3 to 5 and chroma of 2 or less in most of the horizons with mottles and exhibited redoximorphic features like gleying, high chroma mottles and Fe-Mn concretions. Wide variation in sand/silt ratio $(>0.2)$ and uniformity value $(>0.6)$ in these soils indicated lithological discontinuity. The distribution of free $\mathrm{Fe}_{2} \mathrm{O}_{3}$ showing positive correlation with clay contents $\left(\mathrm{r}=0.59^{* *}\right)$ indicate that gleying extends deeper down the profiles. The soils are well saturated with bases (61 to $91 \%$ ) and the CEC/clay ratio of the soils (47-81\%) indicates that the soils belong to a mixed mineralogy family class. The soils are classified as Epiaquepts and Endoaquepts at great group levels. Alternate land use plans developed through soil site suitability for Epiaquepts are transplanted rice in kharif and maize/tomato/ pulses in rabi season. The Endoaquepts can be used to grow deep water rice in kharifl followed by pulses in rabi season. Dugout farm pond and deep drainage channels may be viable options in these low lying Endoauepts for drainage of excess water from the surface and subsurface soils.
\end{abstract}

\section{Introduction}

The Mahanadi river delta of Odisha, the third largest delta in east coast of India occupying an area of $0.90 \mathrm{mha}$ is divided into three demarked geo-morphologic zones South, North and Central. The South Mahanadi Delta comprises parts of Khurda, Cuttack and Puri districts covers an area of 0.178 mha and the tract is drained by rivers Daya, Bhargavi and Kushabhadra, the major distributary branches of Mahanadi river system (Mishra and Jena, 2015). The flow of Daya and part discharge of Bhargavi terminates at a lagoon named Chilika and balance flow is discharged directly or via cuts to Bay of Bengal. The soil of this tract is deltaic alluvium and the landforms comprise of floodplains, alluvial fans, river terraces and meander channels (Mishra and Dwibedy, 2015). In this part of Mahanadi delta, the fluvial processes are dominating over coastal processes resulting vast stretches of flat land with deposition of fluvial sediments (Somanna et al., 2016). The hydrology, morphology, ecology of the area has altered significantly from its period of origin to present. Though this tract is the potential food basket of Puri district, the deltaic topography, flat slopes, heavy texture, supply of water into the delta by rain and irrigation channels have jointly contributed the problem of ill drainage and waterlogging rendering the land unproductive (Mahalik, 2000). Out of 177.7 thousand ha total geographic area of South Mahanadi Delta, 35.6 thousand ha of land are ill drained and waterlogged. The severity of periodical waterlogging in Mahanadi delta due to flat topography, nonuniform and heavy rainfall during southwest monsoon season (June-September) and low density of drainage channels has also been reported by Paul et al. (2014). The Aquepts, the dominant soil suborder in these saturated soils of the region (Sarkar et al., 2005), are the Inceptisols having aquic moisture regime and characteristic redoximorphic features like gleying and mottles and are normally developed in low lying flat areas periodically saturated with water (Soil Survey Staff, 2014). The information on these Aquepts is scanty and the present study is an attempt to characterize these soils under South Mahanadi delta and to develop appropriate management strategies for suitable and sustainable land use options. 


\section{Materials and Methods}

The study area forms a transect in the Puri district under South Mahanadi deltaic region and is located in between $19^{\circ} 50^{\prime} 45^{\prime \prime}$ to $20^{\circ} 08^{\prime} 55^{\prime \prime} \mathrm{N}$ latitude and $85^{\circ} 45^{\prime} 56^{\prime \prime}$ to $85^{\circ} 55^{\prime}$ 50" E longitude (Table 1, Figure 1). The region exhibits hot, moist sub humid climate with average annual rainfall of $1473 \mathrm{~mm}$ and mean maximum and mean minimum

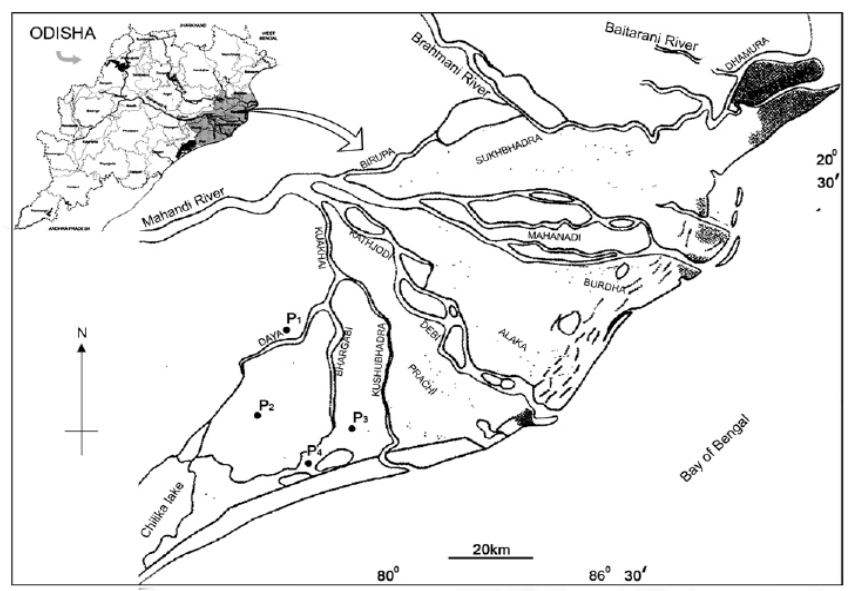

Figure 1: Mahanadi delta of Odisha with profile locations $\left(\mathrm{P}_{1}\right.$, $\left.\mathrm{P}_{2}, \mathrm{P}_{3}, \mathrm{P}_{4}\right)$ in its southern portion

temperature of $31.0^{\circ} \mathrm{C}$ and $23.2{ }^{\circ} \mathrm{C}$, respectively. The length of growing period (LGP) of the tract is around 210 days. Most of the soils in this tract exhibit aquic soil moisture regime as the ground water table fluctuates from 0.8 to 2.2 $\mathrm{m}$ in dry season and are classified as Aquepts as per Soil
Taxonomy. Four representative pedons $\left(\mathrm{P}_{1}, \mathrm{P}_{2}, \mathrm{P}_{3}\right.$ and $\left.\mathrm{P}_{4}\right)$ of these Aquepts belonging to identified Kakuria (Pipili), Nalibasanta (Satyabadi), Gadavingura (Puri Sadar) and Narasinghaballabh (Puri Sadar) series (Sarkar et al., 2005) were prepared in the study area for the purpose during April, 2015. The general characteristics of the pedons are presented in (Table 1). The geology of the tract is alluvium and these alluvial deposits have time span in between upper Cretaceous till date (Mahalik, 2000). The temperature and moisture regimes are hyperthermic and aquic, respectively (Soil Survey Staff, 1999). The morphological characteristics of the soils were studied in detail as per the procedures described in Soil Survey Manual (Soil Survey Staff, 1995). The soils are analyzed for particle size distribution, available water capacity (AWC), $\mathrm{pH}$, organic carbon, free iron oxide, cation exchange capacity and exchangeable bases using standard methods (Jackson, 1956, 1973). The citrate-bicarbonatedithionite extractable iron was estimated by the method outlined by Mehra and Jackson (1960). The CEC/clay ratio was calculated for determination of mineralogy family class. The uniformity value was determined as per formula devised by Cremeens and Mokma (1986). The soils were classified as per 'Keys to Soil Taxonomy' (Soil survey Staff, 2014). The soil site suitability for crops in each series was determined by the procedures described by Sys et al., 1993.

$[($ Silt+very fine sand $) /$

$\begin{aligned} & \text { Uniformity } \\ & \text { value }=\end{aligned} \quad \frac{\text { (Sand-very fine sand })] \text { in upper horizon }}{[(\text { Silt+very fine sand }) /}-1$

(Sand-very fine sand)] in lower horizon

\begin{tabular}{|c|c|c|c|c|c|c|}
\hline $\begin{array}{l}\text { Pedon } \\
\text { No. }\end{array}$ & Location & Block & $\begin{array}{c}\text { Latitude / longitude / } \\
\text { elevation (amsl) }\end{array}$ & $\begin{array}{l}\text { Ground water } \\
\text { table }(\mathrm{m})\end{array}$ & $\begin{array}{l}\text { Distribution } \\
\text { (Thousand ha) }\end{array}$ & Land use \\
\hline $\mathrm{P}_{1}$ & Kakuria & Pipili & $\begin{array}{c}20^{\circ} 08^{\prime} 55^{\prime \prime} \mathrm{N} \\
85^{\circ} 45^{\prime} 56^{\prime \prime} \mathrm{E} 11 \mathrm{~m}\end{array}$ & 1.9 & 46 & $\begin{array}{l}\text { Paddy, bamboo, palm, } \\
\text { rabi greengram }\end{array}$ \\
\hline $\mathrm{P}_{2}$ & $\begin{array}{l}\text { Naliba- } \\
\text { santa }\end{array}$ & Satyabadi & $\begin{array}{c}20^{\circ} 00^{\prime} 31^{\prime \prime} \mathrm{N} \\
85^{\circ} 45^{\prime} 48^{\prime \prime} \mathrm{E} 8 \mathrm{~m}\end{array}$ & 1.6 & 45 & $\begin{array}{l}\text { Paddy, palm, rabi } \\
\text { greengram and horsegram }\end{array}$ \\
\hline $\mathrm{P}_{3}$ & $\begin{array}{l}\text { Gadavin- } \\
\text { gura }\end{array}$ & Puri Sadar & $\begin{array}{c}19^{\circ} 53^{\prime} 22^{\prime \prime} \mathrm{N} \\
85^{\circ} 55^{\prime} 50^{\prime \prime} \mathrm{E} 7 \mathrm{~m}\end{array}$ & 1.3 & 27 & $\begin{array}{l}\text { Paddy, date palm, rabi } \\
\text { horsegram }\end{array}$ \\
\hline $\mathrm{P}_{4}$ & $\begin{array}{l}\text { Narasinh- } \\
\text { gaballabh }\end{array}$ & Puri Sadar & $\begin{array}{c}19^{\circ} 50^{\prime} 45^{\prime \prime} \mathrm{N} \\
85^{\circ} 47^{\prime} 42^{\prime \prime} \text { E } 6 \text { m }\end{array}$ & 1.1 & 22 & $\begin{array}{l}\text { Rabi horsegram and } \\
\text { greengram }\end{array}$ \\
\hline
\end{tabular}

\section{Results and Discussion}

\subsection{Morphological characteristics}

The soils of lower Mahanadi delta mostly have aquic moisture regime due to high ground water table as some of the major distributaries along with their branches are flowing in this tract. The morphological characteristics of these soils are presented in Table 2. The soils are deep and the matrix colour are dominantly gray with hue of $2.5 \mathrm{Y}, 2.5 \mathrm{YR}, 10 \mathrm{YR}$, value of 3 to 5 and chroma of 2 or less in most of the horizons. Chroma of 2 or less in the subsurface horizons indicates the evidence of gleying and redoximorphic features (mottles and concretions) associated with wetness (Bhaskar et al., 2005). Redoximorphic features are more useful than soil colour for indicating soil saturation and reduction occurrences, because they provide specific evidence of where these processes 
operate in the soil (Dezful et al., 2015). Presence of strong brown mottles (7.5YR) in all the pedons with chroma of 4 or more are due to reduction-oxidation conditions created by fluctuation of water table (Veprakas, 1992). The soil texture are mostly fine and varies from silty clay loam to clay and silty clay. The structure varies from weak, medium sub angular blocky at surface to moderate, medium sub angular blocky and strong, coarse angular blocky at subsurface. Development of cambic subsurface horizon is indicated by presence of strong structure in B horizons. Consistence, in general, are slightly hard to hard (dry), friable to firm (moist) and slightly sticky to very sticky, slightly plastic to very plastic (wet).

\begin{tabular}{|c|c|c|c|c|c|c|c|c|c|c|c|c|}
\hline \multirow{2}{*}{$\begin{array}{l}\text { Hori- } \\
\text { zons }\end{array}$} & \multirow{2}{*}{$\begin{array}{c}\mathrm{D} \\
(\mathrm{cm})\end{array}$} & \multirow[t]{2}{*}{$\mathrm{MC}(\mathrm{M})$} & \multirow[t]{2}{*}{$\mathrm{MC}$} & \multirow[t]{2}{*}{$\mathrm{HB}$} & \multirow[t]{2}{*}{$\mathrm{T}$} & \multirow[t]{2}{*}{ Structure } & \multicolumn{3}{|c|}{ Consistence } & \multicolumn{2}{|c|}{ Pores } & \multirow[t]{2}{*}{ Other features } \\
\hline & & & & & & & $\mathrm{D}$ & M & $\mathrm{W}$ & $\mathrm{S}$ & Q & \\
\hline \multicolumn{13}{|c|}{ Pedon 1} \\
\hline Ap & $0-13$ & 10YR4/4 & - & cs & $\mathrm{scl}$ & $\mathrm{m} 1 \mathrm{sbk}$ & sh & $\mathrm{fr}$ & ssps & vf & $\mathrm{c}$ & - \\
\hline A12 & $13-28$ & 10YR4/6 & - & cs & ls & $\mathrm{fl} \mathrm{gr}$ & 1 & 1 & sopo & vf & $\mathrm{f}$ & - \\
\hline $\mathrm{Bg} 1$ & $28-48$ & $2.5 \mathrm{YR} 5 / 2$ & - & gs & sicl & $\mathrm{m} 2 \mathrm{sbk}$ & $\mathrm{sh}$ & fr & ssps & vf & $\mathrm{f}$ & - \\
\hline $\mathrm{Bg} 2$ & $48-70$ & $10 \mathrm{YR} 4 / 3$ & c1p 7.5YR5/8 & gs & sicl & $\mathrm{m} 2 \mathrm{sbk}$ & sh & fr & ssps & - & - & f, m Fe-Mn Concr \\
\hline $\mathrm{Bg} 3$ & $70-92$ & $10 \mathrm{YR} 3 / 2$ & c1p 7.5YR4/8 & gs & sicl & $\mathrm{m} 2 \mathrm{sbk}$ & sh & fr & ssps & - & - & f, m Fe-Mn Concr \\
\hline $\mathrm{Bg} 4$ & $92-132$ & 10YR3/2 & - & - & sicl & $\mathrm{m} 2 \mathrm{sbk}$ & sh & fr & ssps & - & - & - \\
\hline \multicolumn{13}{|c|}{ Pedon 2} \\
\hline Ap & $0-14$ & 10YR4/2 & - & gs & $\mathrm{c}$ & f2 sbk & $\mathrm{h}$ & fi & vsp & $\mathrm{m}$ & $\mathrm{f}$ & \\
\hline Bwg1 & $14-37$ & 10YR5/1 & m3p7.5YR4/6 & gs & $\mathrm{c}$ & $\mathrm{m} 2 \mathrm{sbk}$ & $\mathrm{h}$ & $\mathrm{fr}$ & $\mathrm{sp}$ & $\mathrm{f}$ & $\mathrm{f}$ & $\begin{array}{l}\mathrm{c}, \mathrm{f} \text { Fe-Mn Concr, } \\
\text { pressure faces, cracks }\end{array}$ \\
\hline Bwg2 & $37-63$ & 10YR5/1 & $\mathrm{m} 3 \mathrm{p} 7.5 \mathrm{YR} 5 / 6$ & gs & $\mathrm{c}$ & c3 abk & $\mathrm{h}$ & fr & $\mathrm{sp}$ & $\mathrm{vf}$ & $\mathrm{f}$ & $\begin{array}{l}\text { c, f Fe-Mn Concr, } \\
\text { pressure faces, cracks }\end{array}$ \\
\hline Bwg3 & $63-96$ & $2.5 \mathrm{Y} 5 / 0$ & $\mathrm{~m} 3 \mathrm{p} 7.5 \mathrm{YR} 4 / 5$ & ds & $\mathrm{c}$ & c3 abk & sh & fr & ssp & $\mathrm{vf}$ & $\mathrm{f}$ & $\begin{array}{l}\mathrm{c}, \mathrm{f} \text { Fe-Mn Concr, } \\
\text { pressure faces, cracks }\end{array}$ \\
\hline Bwg4 & $96-150$ & $2.5 \mathrm{Y} 4.5 / 0$ & m3d10YR5/6 & - & $\mathrm{c}$ & vc3 abk & $\mathrm{s}$ & fr & sopo & - & - & $\begin{array}{l}\mathrm{c}, \mathrm{f} \text { Fe-Mn Concr, } \\
\text { pressure faces, cracks }\end{array}$ \\
\hline \multicolumn{13}{|c|}{ Pedon 3} \\
\hline Ap & $0-18$ & $2.5 \mathrm{Y} 4 / 4$ & - & cs & sicl & $\mathrm{m} 1 \mathrm{sbk}$ & $\mathrm{h}$ & fi & ssps & vf & $\mathrm{m}$ & - \\
\hline Bwg1 & $18-56$ & $2.5 \mathrm{Y} 4 / 2$ & clp 7.5YR4/6 & gs & $\mathrm{c}$ & $\mathrm{m} 2 \mathrm{sbk}$ & $\mathrm{h}$ & fi & vsvp & $\mathrm{vf}$ & $\mathrm{m}$ & f, f Fe-Mn Concr \\
\hline Bwg2 & $56-94$ & $2.5 \mathrm{Y} 3 / 3$ & $\mathrm{c} 2 \mathrm{p} 7.5 \mathrm{YR} 4 / 4$ & gs & $\operatorname{sic}$ & $\mathrm{m} 2 \mathrm{sbk}$ & $\mathrm{h}$ & fi & vsvp & $\mathrm{f}$ & $\mathrm{c}$ & f, f Fe-Mn Concr \\
\hline Bwg3 & $94-146$ & $2.5 \mathrm{Y} 3 / 2$ & $\mathrm{c} 2 \mathrm{p} 7.5 \mathrm{YR} 4 / 6$ & - & $\operatorname{sic}$ & $\mathrm{m} 3 \mathrm{sbk}$ & $\mathrm{h}$ & fi & vsvp & $\mathrm{f}$ & $\mathrm{c}$ & f, c Fe-Mn Concr \\
\hline \multicolumn{13}{|c|}{ Pedon 4} \\
\hline Ap & $0-13$ & 10YR3/3 & - & gs & $\mathrm{c}$ & $\mathrm{m} 2 \mathrm{sbk}$ & $\mathrm{h}$ & fi & $\mathrm{sp}$ & vf & $\mathrm{m}$ & - \\
\hline $\mathrm{Bg} 1$ & $13-42$ & 10YR3/2 & - & gs & $\mathrm{c}$ & $\mathrm{m} 2 \mathrm{sbk}$ & $\mathrm{h}$ & fi & $\mathrm{sp}$ & $\mathrm{vf}$ & $\mathrm{m}$ & - \\
\hline $\mathrm{Bg} 2$ & $42-74$ & 10YR5/2 & fld 7.5YR4/6 & cs & $\mathrm{scl}$ & $\mathrm{m} 2 \mathrm{sbk}$ & sh & fi & $\mathrm{ssp}$ & $\mathrm{vf}$ & $\mathrm{m}$ & f, f Fe-Mn Concr. \\
\hline $\mathrm{Bg} 3$ & $74-104$ & 10YR5/1 & f1d 7.5YR4/6 & cs & $\mathrm{c}$ & m (massive) & $\mathrm{h}$ & fi & $\mathrm{sp}$ & - & - & - \\
\hline $\mathrm{Bg} 4$ & $104-132$ & $2.5 \mathrm{YR} 4 / 0$ & $\mathrm{~m} 1 \mathrm{~d} 7.5 \mathrm{YR} 4 / 4$ & - & sic & m (massive) & $\mathrm{h}$ & fi & $\mathrm{sp}$ & - & - & - \\
\hline
\end{tabular}

Abbre- Matrx colour: M-Moist; Mottle colour: f-few; c-common; m-many; 1-fine; 2-medium; 3-coarse; p-prominent; viation d-distinct; Horizon boundary: c-clear, g-gradual, d-diffuse; Texture: scl-sandy clay loam, ls-loamy sand, siclsilty clay loam, c-clay, sic-silty clay, Structure: m-medium, f-fine, c-coarse, vc-very coarse,1-weak, 2-moderate, 3-strong, sbk-sub angular blocky, gr-granular, abk-angular blocky, Consistence: D (dry), sh-slightly hard, 1-loose, h-hard, M(moist), fr-friable, l-loose, fi-firm, W(wet), so-non sticky, ss-slightly sticky, s-sticky, vs-very sticky, ponon plastic, ps-slightly plastic, p-plastic, vp-very plastic; Pores/Concretions (Concr) : S(size), vf-very fine, f-fine, m-medium, c-coarse, Q(quantity), f-few, c-common, m-many

D (cm): Depth (cm); MC (M): Matrix colour (M); MC: Mottle colour; HB: Horizon boundary; T: Texture 
The vertic properties of the soils of pedon 2 were evidenced by presence of 2-3 cm wide cracks up to a depth of $40 \mathrm{~cm}$ and shining pressure faces. Saturated condition in $\mathrm{Bg} 1$ and again in $\mathrm{Bg} 3$ and $\mathrm{Bg} 4$ horizons (chroma of 2), unsaturated condition in $\mathrm{Bg} 2$ (chroma of 3), redox concentration (Fe and $\mathrm{Mn}$ concretion) at depth of $48-90 \mathrm{~cm}$, redox depletion (mobilization of $\mathrm{Fe}$ and $\mathrm{Mn}$ out of horizon) at depth of 26$48 \mathrm{~cm}$ and $90-130 \mathrm{~cm}$ and presence of high chroma mottles indicated the characteristics of episaturation (Bhattacharya et al., 1997) in pedon 1. Saturated condition in all the layers due to fluctuation of ground water table from nearly level to below $50 \mathrm{~cm}$ depth, evidence of redox concentration, redox depletion and high chroma mottles show the characteristics of endosaturation (Soil Survey Staff, 1999) in pedon 2, 3 and 4.

3.2. Particle size distribution and available water capacity
$(A W C)$

The texture of these deltaic soils are relatively fine (Table 3 ) except A12 horizon of pedon 1 with clay content ranging from 15.4 to $63.5 \%$ and the irregular distribution of soil separates in the profiles could be due to different type of sediments with different textures deposited over the years (Azagaku and Idoga, 2012). An abrupt increase in clay contents in B horizon of pedon 1, without any sign of argillic sub surface horizon is indicative of lessivage (Singh and Agrawal, 2005). The high inflections in sand/silt ratio ( 0.2 or more) in these soils indicated lithological discontinuity which might be due to the deposition of sediments in different fluvial cycles (Gangopadhyay et al., 1998). Lithological breaks in these soils are also evidenced by wide variation in uniformity values of more than 0.6 (Cremeens and Mokra, 1986). The

Table 3: Particle size distribution and available water capacity (AWC)

\begin{tabular}{|c|c|c|c|c|c|c|c|c|c|c|}
\hline \multirow[t]{4}{*}{ Horizons } & \multirow{4}{*}{$\begin{array}{l}\text { Depth } \\
(\mathrm{cm})\end{array}$} & \multicolumn{6}{|c|}{ Particle size distribution $(\%)(<2.0 \mathrm{~mm})$} & \multirow[t]{4}{*}{ UV } & \multirow{4}{*}{$\begin{array}{l}\text { Sand / } \\
\text { silt }\end{array}$} & \multirow{4}{*}{$\begin{array}{c}\text { AWC } \\
\%\end{array}$} \\
\hline & & \multicolumn{4}{|c|}{ Sand } & \multirow{2}{*}{ Silt } & \multirow{2}{*}{ Clay } & & & \\
\hline & & Medium & Fine & Very fine & Total & & & & & \\
\hline & & $0.5-0.25$ & $0.25-0.1$ & $0.1-0.05$ & $2.0-0.05$ & $0.05-0.002$ & $<0.002$ & & & \\
\hline \multicolumn{11}{|l|}{ Pedon 1} \\
\hline Ap & $0-13$ & 3.0 & 10.7 & 43.1 & 56.8 & 15.5 & 27.7 & - & 3.62 & 13.4 \\
\hline A12 & $13-28$ & 7.0 & 15.8 & 61.8 & 84.6 & 6.7 & 8.7 & 0.43 & 12.03 & 4.0 \\
\hline $\mathrm{Bg} 1$ & $28-48$ & 0.8 & 2.5 & 9.8 & 13.1 & 52.2 & 34.7 & -0.82 & 0.26 & 17.4 \\
\hline $\mathrm{Bg} 2$ & $48-70$ & 0.4 & 1.2 & 5.7 & 7.3 & 62 & 30.7 & -0.54 & 0.12 & 17.4 \\
\hline $\mathrm{Bg} 3$ & $70-92$ & 0.3 & 1.2 & 4.4 & 5.9 & 60.4 & 33.7 & -0.01 & 0.10 & 17.5 \\
\hline $\mathrm{Bg} 4$ & $92-132$ & - & 1.4 & 4 & 5.4 & 63.5 & 31.1 & -0.10 & 0.09 & 17.6 \\
\hline \multicolumn{11}{|l|}{ Pedon 2} \\
\hline Ap & $0-14$ & 3.9 & 8.8 & 14.8 & 25.5 & 19.6 & 54.9 & - & 1.27 & 16.9 \\
\hline Bwg1 & $14-37$ & 3 & 6.2 & 12.2 & 21.4 & 17.6 & 61 & -0.01 & 1.18 & 17.2 \\
\hline Bwg2 & $37-63$ & 1.4 & 2.6 & 10.5 & 14.5 & 21.7 & 63.8 & -0.60 & 0.65 & 17.7 \\
\hline Bwg3 & 63-96 & 1.5 & 6.5 & 15.3 & 23.3 & 15.4 & 61.3 & 1.08 & 1.47 & 17.4 \\
\hline Bwg4 & $96-150$ & 2.4 & 7 & 17.2 & 26.6 & 15.9 & 57.5 & 0.10 & 1.64 & 17.1 \\
\hline \multicolumn{11}{|l|}{ Pedon 3} \\
\hline $\mathrm{Ap}$ & $0-18$ & 2.4 & 4.2 & 9.4 & 16 & 49.9 & 34.1 & - & 0.32 & 17.8 \\
\hline Bwg1 & $18-56$ & 2.8 & 6.6 & 11.4 & 20.8 & 31.4 & 47.8 & 0.86 & 0.65 & 17.2 \\
\hline Bwg2 & $56-94$ & 1.2 & 3.1 & 6.2 & 10.5 & 42.2 & 47.3 & -0.56 & 0.25 & 18.1 \\
\hline Bwg3 & $94-146$ & 0.6 & 1.6 & 5.4 & 7.6 & 45.6 & 46.8 & -0.50 & 0.17 & 18.3 \\
\hline \multicolumn{11}{|l|}{ Pedon 4} \\
\hline $\mathrm{Ap}$ & $0-13$ & 0.6 & 1.8 & 3.8 & 6.2 & 33.7 & 60.1 & - & 0.18 & 17.5 \\
\hline $\mathrm{Bg} 1$ & $13-42$ & 2.6 & 4.2 & 8.8 & 15.6 & 31.3 & 53.7 & 1.65 & 0.50 & 16.8 \\
\hline $\mathrm{Bg} 2$ & $42-74$ & 3.5 & 9.3 & 39.4 & 52.2 & 21.7 & 26.1 & 0.24 & 2.41 & 13.2 \\
\hline $\mathrm{Bg} 3$ & 74-104 & 2.8 & 7.6 & 15.8 & 26.2 & 32.1 & 41.7 & 0.04 & 0.82 & 16.4 \\
\hline $\mathrm{Bg} 4$ & $104-132$ & 2.0 & 2.4 & 6.2 & 10.6 & 45.7 & 43.7 & -0.61 & 0.23 & 17.9 \\
\hline
\end{tabular}

UV: Uniformity value; AWC: Available water capacity 
higher contents of fine sand, very fine sand and silt in all these soils are indicative of deposition by overbank flooding. The available water capacity (AWC) of these soils showed significant positive correlation with silt content $\left(\mathrm{r}=0.52^{*}\right)$, clay content $\left(\mathrm{r}=0.65^{* *}\right)$ and silt plus clay content $\left(\mathrm{r}=0.92^{* *}\right)$ of different horizons.

\subsection{Chemical characteristics}

The soils are slightly acidic in the surface and almost neutral in the subsurface horizons (Table 4). The increasing trend of $\mathrm{pH}$ with soil depth in pedon 1 and 3 might be due to less weathering as well as high ground water table during some parts of the year (Karmakar et al., 1999). The organic carbon (OC) content of the surface soils are medium to high and are gradually decreasing with depth in pedon 2 and 4, whereas, in pedon 1 and 3, the distribution is uneven. The abrupt increase in organic carbon in the lower most layers of pedon 1 and 3 might be due to deposition of fresh alluvium over vegetation of an earlier period (Bandyopadhyay et al., 1984). The distribution of free $\mathrm{Fe}_{2} \mathrm{O}_{3}$ indicate that gleying extends deeper down the profiles and this is attributed to the reduction and subsequent mobility of iron $\left(\mathrm{Fe}^{2+}\right)$ at grater depths. Higher clay content in the subsurface horizons absorbs more iron leached from subsurface horizons (Bhattacharyya et al., 1997) and for soils with deeper gleying, this distribution of iron is more conspicuous. The significant positive correlation of free $\mathrm{Fe}_{2} \mathrm{O}_{3}$ with clay contents in horizons $\left(\mathrm{r}=0.59^{* *}\right)$ corroborates the above findings. High CEC of these soils and variation in their distribution might be attributed to the clay content $\left(\mathrm{r}=0.95^{* *}\right)$. The exchange complex of the soils is dominated with calcium and magnesium and the soils are highly saturated with bases (61 to 91\%). The exchangeable

\begin{tabular}{|c|c|c|c|c|c|c|c|c|c|c|c|c|}
\hline \multirow[t]{3}{*}{ Horizons } & \multirow{3}{*}{$\begin{array}{l}\text { Depth } \\
(\mathrm{cm})\end{array}$} & \multirow{3}{*}{$\begin{array}{c}\mathrm{pH} \\
(1: 2.5)\end{array}$} & \multirow{3}{*}{$\begin{array}{c}\text { Free } \\
\mathrm{Fe}_{2} \mathrm{O}_{3} \\
(\%)\end{array}$} & \multirow{3}{*}{$\begin{array}{c}\mathrm{OC} \\
\left(\mathrm{g} \mathrm{kg}^{-1}\right)\end{array}$} & \multirow[t]{3}{*}{ CEC } & \multicolumn{4}{|c|}{ Exchangeable cations } & \multirow{3}{*}{$\begin{array}{l}\text { BS } \\
(\%)\end{array}$} & \multirow{3}{*}{$\begin{array}{c}\text { CEC/clay } \\
(\%)\end{array}$} & \multirow{3}{*}{$\begin{array}{l}\text { ESP } \\
(\%)\end{array}$} \\
\hline & & & & & & $\mathrm{Ca}$ & $\mathrm{Mg}$ & $\mathrm{Na}$ & $\mathrm{K}$ & & & \\
\hline & & & & & & \multicolumn{4}{|c|}{$\mathrm{c} \mathrm{mol}\left(\mathrm{p}^{+}\right) \mathrm{kg}^{-1}$} & & & \\
\hline \multicolumn{13}{|l|}{ Pedon 1} \\
\hline Ap & $0-13$ & 5.4 & 0.6 & 6.5 & 12.7 & 5.9 & 2.3 & 0.3 & 0.2 & 69 & 46 & 2.4 \\
\hline A12 & $13-28$ & 6.3 & 0.1 & 1.1 & 6.6 & 3.6 & 1.4 & 0.2 & 0.1 & 80 & 76 & 3.0 \\
\hline $\mathrm{Bg} 1$ & $28-48$ & 7.2 & 1.6 & 4.4 & 21.8 & 10.7 & 7.7 & 0.7 & 0.2 & 89 & 63 & 3.2 \\
\hline $\mathrm{Bg} 2$ & $48-70$ & 7.2 & 2.7 & 4.3 & 21.4 & 10.5 & 7.6 & 0.8 & 0.2 & 89 & 70 & 3.7 \\
\hline $\mathrm{Bg} 3$ & $70-92$ & 7.3 & 2.1 & 4.2 & 22.0 & 10.8 & 8.2 & 0.9 & 0.2 & 91 & 65 & 4.1 \\
\hline $\mathrm{Bg} 4$ & $92-132$ & 7.4 & 1.9 & 4.7 & 21.8 & 11.4 & 8.1 & 0.9 & 0.2 & 94 & 70 & 4.1 \\
\hline \multicolumn{13}{|l|}{ Pedon 2} \\
\hline Ap & $0-14$ & 5.3 & 0.8 & 6.0 & 37.2 & 14.8 & 9.4 & 1.9 & 1.0 & 73 & 68 & 5.1 \\
\hline Bwg1 & $14-37$ & 5.5 & 3.1 & 4.7 & 39.4 & 17.6 & 10.5 & 2.1 & 1.3 & 80 & 65 & 5.3 \\
\hline Bwg2 & $37-63$ & 6.1 & 3.5 & 2.7 & 42.8 & 18.4 & 13.7 & 2.3 & 1.4 & 84 & 67 & 5.4 \\
\hline Bwg3 & $63-96$ & 6.6 & 3.2 & 2.1 & 42.4 & 19.6 & 14.5 & 2.2 & 1.4 & 89 & 69 & 5.2 \\
\hline Bwg4 & $96-150$ & 6.8 & 3.1 & 1.6 & 40.5 & 18.2 & 13.9 & 2.2 & 1.3 & 88 & 70 & 5.4 \\
\hline \multicolumn{13}{|l|}{ Pedon 3} \\
\hline Ap & $0-18$ & 5.7 & 0.7 & 7.7 & 21.8 & 9.2 & 4.4 & 1.9 & 0.8 & 75 & 64 & 8.7 \\
\hline Bwg1 & $18-56$ & 7.0 & 3.0 & 2.7 & 29.6 & 15.5 & 7.2 & 2.1 & 0.7 & 86 & 62 & 7.1 \\
\hline Bwg2 & 56-94 & 7.2 & 2.9 & 2.8 & 35.8 & 17.4 & 10.8 & 2.2 & 0.8 & 87 & 76 & 6.1 \\
\hline Bwg3 & $94-146$ & 7.4 & 2.8 & 4.1 & 38.0 & 17.9 & 11.5 & 2.1 & 0.9 & 85 & 81 & 5.5 \\
\hline \multicolumn{13}{|l|}{ Pedon 4} \\
\hline Ap & $0-13$ & 5.8 & 0.9 & 9.4 & 36.4 & 14.6 & 10.4 & 0.7 & 0.5 & 72 & 61 & 1.9 \\
\hline $\mathrm{Bg} 1$ & $13-42$ & 6.4 & 3.5 & 7.0 & 30.0 & 14.4 & 10.2 & 0.6 & 0.2 & 85 & 56 & 2.0 \\
\hline $\mathrm{Bg} 2$ & $42-74$ & 6.5 & 2.1 & 3.6 & 14.6 & 7.5 & 4.6 & 0.6 & 0.2 & 88 & 56 & 4.1 \\
\hline $\mathrm{Bg} 3$ & $74-104$ & 6.6 & 2.4 & 3.2 & 21.9 & 11.6 & 6.3 & 0.7 & 0.4 & 87 & 53 & 3.2 \\
\hline $\mathrm{Bg} 4$ & 104-132 & 6.5 & 2.2 & 1.1 & 25.2 & 13.2 & 7.2 & 0.6 & 0.4 & 85 & 58 & 2.4 \\
\hline
\end{tabular}

OC: Organic carbon; CEC: Cation exchange capacity; BS: Base saturation; ESP: Exchangeable sodium percentage 
sodium percentage (ESP) of the soils varies from 1.9 to $8.7 \%$. The CEC/clay ratio of the soils (47-81\%) indicates that the soils belong to a mixed mineralogy family class (Smith Guy, 1986).

\subsection{Soil classification}

The soils under lower Mahanadi delta are Aquepts as the ground water commonly fluctuates from a level near the surface to below a depth of $50 \mathrm{~cm}$. The soils of pedon 1 are classified as Fuvaquentic Epiaquepts as they exhibit the conditions of episaturation, irregular decrease of $\mathrm{OC}$ and at depth of $125 \mathrm{~cm}$ below the mineral soil surface, OC of $0.2 \%$ or more. Pedon 2, 3 and 4 belong to great group Endoaquepts as all the horizons show characteristic saturation with matrix chroma of 2 or less and redoximorphic features like mottles, Fe-Mn concretions. Pedon 2 is placed under Vertic Endoaquepts as they have $2-3 \mathrm{~cm}$ wide cracks up to a depth of $40 \mathrm{~cm}$ and pressure faces. Pedon 3 is under Aeric Endoaquepts as it has a horizon within upper $75 \mathrm{~cm}$ that has a chroma of 3 (Bwg2, 56-94 cm) and somewhat deeper ground water table $(2 \mathrm{~m})$ than pedon 4 . Pedon 4 is classified under Typic Endoaquepts as they exhibit regular decrease in OC down the depth and less than $0.2 \%$ OC at a depth of $125 \mathrm{~cm}$ below mineral soil surface.

\subsection{Land use interpretation}

Land evaluation for crops through soil site suitability in these soils is presented in (Table 5). The limitation identified in Kakuria $\left(\mathrm{P}_{1}\right)$ and Nalibasanta $\left(\mathrm{P}_{2}\right)$ series are texture $(\mathrm{s})$, drainage (w), organic carbon (f) and slope $(t)$, whereas, the soils of Godavingura $\left(\mathrm{P}_{3}\right)$ and Narasinghballabh $\left(\mathrm{P}_{4}\right)$ series exhibit limitations in organic carbon (f), texture (s), drainage (w) and flooding (w). The soils of Kakuria (P1), Nalibasanta $\left(\mathrm{P}_{2}\right)$ and Gadavingura $\left(\mathrm{P}_{3}\right)$ are moderately to marginally suitable for rice, rabi maize, rabi groundnut and pulses due to the limitations of flooding, texture, soil fertility and topography. Except Kakuria series $\left(\mathrm{P}_{1}\right)$, all the soils are not suitable for tomato due to severe limitations of flooding and heavy texture. Similarly the soils of Narasinghballabh series (P4) are only moderately suitable for rice with the limitations

Table 5: Soil site suitability for crops

\begin{tabular}{lcccccc}
\hline Soils & $\begin{array}{c}\text { Rice } \\
(\text { kharif })\end{array}$ & $\begin{array}{c}\text { Maize } \\
(\text { rabi })\end{array}$ & $\begin{array}{c}\text { Groundnut } \\
(\text { rabi })\end{array}$ & Tomato & $\begin{array}{c}\text { Greengram/blackgram } \\
\text { (Paira/rabi) }\end{array}$ & $\begin{array}{c}\text { Rice } \\
(\text { rabi })\end{array}$ \\
\hline $\mathrm{P}_{1}$ - Kakuria series & $\mathrm{S}_{3} \mathrm{sw}$ & $\mathrm{S}_{2} \mathrm{wf}$ & $\mathrm{S}_{2} \mathrm{ws}$ & $\mathrm{S}_{3} \mathrm{fw}$ & $\mathrm{S}_{2} \mathrm{wf}$ & $\mathrm{S}_{2}$ \\
$\mathrm{P}_{2}$ - Nalibasanta series & $\mathrm{S}_{2} \mathrm{ft}$ & $\mathrm{S}_{3} \mathrm{ws}$ & $\mathrm{S}_{3} \mathrm{ws}$ & $\mathrm{N}_{2} \mathrm{ws}$ & $\mathrm{S}_{3} \mathrm{ws}$ & $\mathrm{S}_{2} \mathrm{w}$ \\
$\mathrm{P}_{3}$ - Gadavingura series & $\mathrm{S}_{2} \mathrm{ft}$ & $\mathrm{S}_{3} \mathrm{ws}$ & $\mathrm{S}_{3} \mathrm{ws}$ & $\mathrm{N}_{2} \mathrm{ws}$ & $\mathrm{S}_{3} \mathrm{ws}$ & $\mathrm{S}_{2} \mathrm{w}$ \\
$\mathrm{P}_{4}$ - Narasinghaballabh series & $\mathrm{S}_{2} \mathrm{ft}$ & $\mathrm{N}_{2} \mathrm{ws}$ & $\mathrm{N}_{2} \mathrm{ws}$ & $\mathrm{N}_{2} \mathrm{ws}$ & $\mathrm{N}_{2} \mathrm{ws}$ & $\mathrm{S}_{2} \mathrm{w}$ \\
\hline
\end{tabular}

$\mathrm{S}_{1}$ : Suitable; $\mathrm{S}_{2}$ : Moderately suitable; $\mathrm{S}_{3}$ : Marginally suitable; $\mathrm{N}_{2}$ : Permanently not suitable

of heavy texture and severe flooding. The suggested intervention include raised bed and sunken bed technology for the soils of Kakuria series $\left(\mathrm{P}_{1}\right)$ and dugout farm pond, deep drainage channel for the soils of Nalibasanta, Gadavingura and Narasinghballabh series $\left(\mathrm{P}_{2}, \mathrm{P}_{3}\right.$ and $\left.\mathrm{P}_{4}\right)$.

\section{Conclusion}

The deposited soils of South Mahanadi delta are mostly Aquepts with high ground water table, stratified and show the evidence of characteristic redoximorphic features. The Kakuria series $\left(\mathrm{P}_{1}\right)$ belongs to Epiauepts, whereas, Nalibasanta, Gadavingura and Narasinghballabh series $\left(\mathrm{P}_{2}, \mathrm{P}_{3}\right.$ and $\left.\mathrm{P}_{4}\right)$ are under Endoaquepts. The suggested land management options for Epiaquepts are raised bed and sunken bed technology and for Endoaquepts are dugout farm ponds and deep drainage channels to remove excess water from the surface and saturated soil profiles.

\section{Acknowledgement}

The authors are grateful to the Department of Soil Science and Agricultural Chemistry, Orissa University of Agriculture and Technology for providing the logistics and funding to carry out the study.

\section{References}

Azagaku, E.D., Idoga, S., 2012. Rainfed rice productivity potentials of river Katsina Ala floodplain soils of Agasha, Benue state, Nigeria. ARPN Journal of Agricultural and Biological Science 7(11), 933-938.

Bandyopadhyay, A.K., Bhargava, G.P., Bandyopadhyay, B.K., 1984. Coastal saline soils of Orissa, Central Soil Salinity Research Institute (ICAR), Regional Research Station, Canningtown, West Bengal, 56.

Bhattacharyya, T., Baruah, U., Gangopadhyay, S.K., Kumar D., 1997. Characterization of some Aquepts occurring in Assam valley. Journal of the Indian Society of Soil Science 45, 791-796.

Bhaskar, B.P., Baruah, U., Vadivelu, S., Butte, P.S., 2005. Characterization of soils in the 'Bil' environs of Brahmaputra valley in Jorhat district, Assam for land use interpretation. Journal of the Indian Society of Soil Science 53, 3-10. 
Cremeens, D.L., Mokma, D.L., 1986. Argillic horizon expression and classification in the soils of two Michigan hydrosequences. Soil Science Society of America Journal 50, 1002-1007.

Dezful, M.A., Mahmoudi, S., Abadi, M.H.M., Naseri, A.A., 2015. Soil morphology as an indicator for assessment of drainage system efficiency in sugarcane cultivated lands, South Khuzestan, Iran. Eurasian Journal of Soil Science 4(4), 234-243.

Gangopadhyay, S.K., Walia, C.S., Chamuah, G.S., Baruah, U., 1998. Rice growing soils of Upper Brahmaputra valley of Assam-Their characteristics and suitability. Journal of the Indian Society of Soil Science 46, 103109.

Jackson, M.L., 1956. Soil Chemical Analysis, Advanced Course, University of Wisconsin, Madison, USA, 895.

Jackson, M.L., 1973. Soil Chemical Analysis, Oxford IBH Publishing House, Bombay, 498.

Karamkar, R.M., Rao, A.F.V., 1999. Soils of different physiographic units in lower Brahmaputra valley zone of Assam: II. Sand mineralogy. Journal of the Indian Society of Soil Science 47, 767-770.

Mahalik, N.K., 2000. Mahanadi delta: geology, resources and biodiversity, Published by Asian Institute of Technology Alumni Association (India Chapter), New Delhi, 169.

Mehra, O.P., Jackson, M.L., 1960. Iron oxide removal from soils and clays by dithionite-citrate system buffered with sodium bicarbonate. In: Proceedings of the $7^{\text {th }}$ National Conference on Clays and Clay Minerals, Pergamon, New York 317-327.

Mishra, S.P., Dwibedy, S., 2015. Geohydrology of south Mahanadi delta and Chilka lake, Odisha. International Journal of Advanced Research 3(11), 430-445.

Mishra, S.P., Jena, J., 2015. Morphological reconstruction of southern Mahanadi delta and Chilka lagoon, India-a critical case study. International Journal of Advanced Research 3(5), 691-702.
Paul, J.C., Panigrahi, B., Behera, B.P., Patnaik, P.K., 2014. Design of surface drainage system for managing water congestion in Mahanadi delta: A case study. Journal of Agricultural Engineering 51(1), 44-50.

Sarkar, D., Sah, K.D., Sahoo, A.K., Gajbhiye, K.S., 2005. Soil Series of Orissa, NBSS Publ.No.119, National Bureau of Soil Survey and Land Use Planning (ICAR), Nagpur, 254.

Singh, I.S., Agrawal, H.P., 2005. Characterization, genesis and classification of rice soils of eastern region of Varanasi, Uttar Pradesh. Agropedology 15(1), 29-38.

Smith Guy, D., 1986. The Guy Smith Interviews: Rationale for Concepts in Soil Taxonomy, SMSS Technical Monogram, 11 SMSS, SCS, USDA.

Soil Survey Staff, 1995. Soil Survey Manual. United States Department of Agriculture Handbook No. 18, New Revised Edition, Scientific Publishers, Jodhpur, India, 437.

Soil Survey Staff, 1999. Soil Taxonomy, Second Edition, Agriculture Handbook 436, United States Department of Agriculture, Washington DC, 871.

Soil Survey Staff, 2014. Keys to Soil Taxonomy, Twelfth Edition, NRCS, United States Department of Agriculture, Washington DC, 372.

Somanna, K., Reddy, T.S., Rao, M.S., 2016. Geomorphology and evolution of the modern mahanadi delta using remote sensing data. International Journal of Science and Research 5(2), 1329-1335.

Sys, C., Van Ranst, E., Debaveye, J., Beernaert, F., 1993. Land evaluation, Part III, Crop Requirements. Agricultural publication No. 7, International Training centre for Post-Graduate Soil Studies, University of Ghent, Belgium, 191.

Veprakas, M.J., 1992. Redoximorphic features for identifying aquic conditions, Technical Bulletin 301, North Carolina Agricultural Research Service, North Carolina State University, Raleigh NC, 33. 